Белькович Анастасия Павловна,

бакалавр, Иркутский национальный исследовательский технический университет, e-mail: belkovich-a@mail.ru

Лебедева Оксана Викторовна,

к.х.н., доцент, Иркутский национальный исследовательский технический университет,

КОМПЛЕКС ПОЛИ-1-ВИНИЛ-1,2,4-ТРИАЗОЛА И

ФЕНОЛ-2,4-ДИСУЛЬФОКИСЛОТЫ КАК ОСНОВА ИОНООБМЕННОЙ МЕМБРАНЫ ДЛЯ ТОПЛИВНОГО ЭЛЕМЕНТА

Belkovich A.P., Lebedeva O.V.

\title{
POLY-1-VINYL-1,2,4-TRIAZOLE AND PHENOL-2,4-DISULFONIC ACID COMPLEX AS THE BASIS OF ION-EXCHANGE MEMBRANE FOR FUEL CELLS
}

\begin{abstract}
Аннотация. В работе исследованы свойства полимерной мембраны для водородных топливных элементов. Мембрана была синтезирована на основе поли-1-винил-1,2,4-триазола и фенол-2,4-дисульфокислоты в трех стехиометрических соотношениях. Наибольший показатель протонной проводимости продемонстрировал образец ПВТ-ФДСК $\left(10: 90 \%\right.$ масс.) $-5.98 \cdot 10^{-2}$ $\mathrm{CM} / \mathrm{cm}$.
\end{abstract}

Ключевые слова: топливный элемент, ионообменные мембраны, водородный топливный элемент, поли-1-винил-1,2,4-триазол, фенол-2,4-дисульфокислота.

Abstract. In this study, the properties of the polymer membrane for hydrogen fuel cells were investigated.The membrane was based on poly-1-vinyl-1,2,4-triazole and phenol-2,4-disulfonic acid in three stoichiometric ratios. The highest proton conductivity index was demonstrated by the PVT-FDSA sample (10:90\% wt.) $-5.98 \cdot 10-2 \mathrm{~S} / \mathrm{cm}$.

Keywords: fuel cell, ion-exchange membranes, hydrogen fuel cell, poly-1-vinyl-1,2,4-triazole, phenyl-2,4-disulfonic acid.

Протонообменные мембранные топливные элементы (топливные ячейки) - это устройства, способные преобразовывать энергию протона водорода, образованного из газообразного водорода, в электрическую энергию[1]. Ключевым компонентом устройства является мембранно-электродный узел, который состоит из двух электродов, разделенных протонообменной мембраной [2]. Электроды обеспечивают массовый перенос реагентов и удаление образующейся в ходе реакции воды. Мембрана, в свою очередь, должна отвечать ряду таких требований, как: высокая протонная проводимость, низкая газовая проницаемость, высокая механическая и термическая стабильность. Наиболее известной и часто используемой в данное время является ионообменная мембрана типа Нафион. Она характеризуется высокой протонной проводимостью ( 100 мСм/см) [3], которая зависит от условий работы топливного элемента. При пониженной влажности уменьшается ионная подвижность, вследствие чего проводимость мембраны и ее механическая стабильность заметно ухудшаются [4]. Также мембраны типа Нафион характеризуются высокой стоимостью, поэтому в настоящее время идет активная разработка ионообменных мембран, 
отвечающих необходимым фризическим, химическим и экономическим требованиям.

Нами была получена мембрана на основе поли-1-винил-1,2,4-триазола и фенол-2,4-дисульфокислоты (ПВТ-ФДСК) в соотношении 40:60, 10:90 и 80:20 \% масс. На рисунке представлено соотношение проводимостей мембраны при разных массовых соотношениях компонентов.

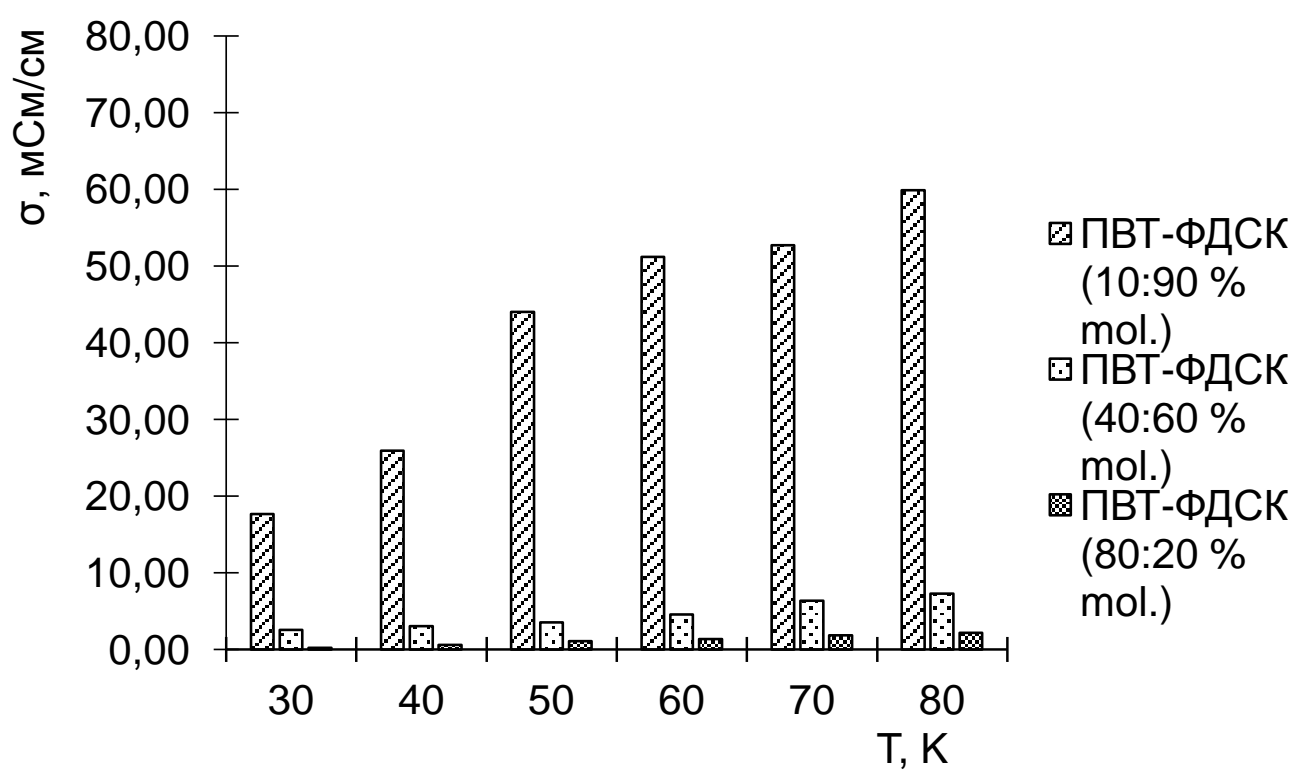

Рисунок - Протонная проводимость мембран ПВТ-ФДСК

Протонная проводимость мембран составила: ПВТ-ФДСК (40:50 \% масс.)

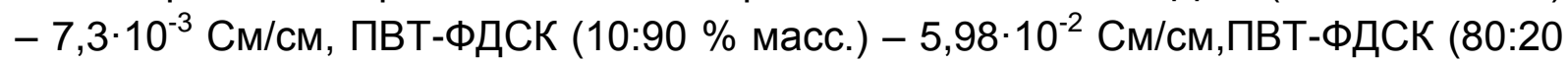
$\%$ масс.) $-6,23 \cdot 10^{-3}$ См/см.

Состав и строение мембраны были изучены методами элементного анализа, ТГ, ИК и ЯМР спектроскопией.

\section{ЛИТЕРАТУРА}

1. Корчагин О.В., Тарасевич М.Р. Токогенерирующие реакции в топливных элементах с протонпроводящим и анионпроводящим электролитами // Электрохимическая энергетика - 2014. - Т. 14. - № 3. - С. 117-132.

2. Authayanun S., Im-orb K., Arpornwichanop A. A review of the development of high temperature proton exchange membrane fuel cells // Chin. J. Catal. 2015. Vol. 36. P. 473-483.

3. Araya S. S., Zhou F., Liso V., Sahlin S. L., Vang J. R., Thomas S., etc. A comprehensive review of PBI-based high temperature PEM fuel cells // Int. J. Hydrogen Energy. 2016. Vol. 41. P. 21310-21344.

4. Nayak R., Sundarraman M., Ghosh P. C., Bhattacharyya A. R. Doped poly (2, 5-benzimidazole) membranes for high temperature polymer electrolyte fuel cell: Influence of various solvents during membrane casting on the fuel cell performance // Eur. Polym. J. 2018. Vol. 100. P. 111-120. 